\title{
Optimizing Strategy To Leverage Profit Of A Home Industry
}

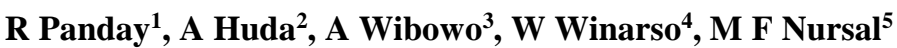 \\ \{Indripan@gmail.com ${ }^{1}$, amrilhuda69@gmail.com² ${ }^{2}$, noor.fikri@gmail.com ${ }^{3}$, \\ widi.winarso@dsn.ubharajaya.ac.id ${ }^{4}$, fadhli.nursal@dsn.ubharajaya.ac.id $\left.{ }^{5}\right\}$ \\ 1,2,3,4,5 Universitas Bhayangkara Jakarta Raya, Jl. Darmawangsa 1 No. 1, Pulo, Kec. Kebayoran Baru, \\ Jakarta Selatan, Indonesia
}

\begin{abstract}
Micro small and medium enterprise (SME) is a business type with a small to medium amount of capital and fast cash turnover because most of the businesses are generally retailing. As a retail, the selling price and quality of their products are competing with each other. Therefore, a proper strategy is needed in order to leverage their profits. One of the strategies is through optimizing the production process. This case study was conducted in a garment industry in Indonesia producing a variety of clothes. Through a linear programming and sensitivity analysis, the most optimum process was found. By applying the suggested process, the company is projected to be able to increase its profits from $24 \%$ to $33 \%$. This study significantly contributes to the micro SMEs, especially the garment industry in planning proper strategies in order to increase its profits.
\end{abstract}

Keywords: profit, optimization, linear programming, sensitivity analysis, micro small and medium enterprises, garment industry

\section{Introduction}

Home industry is a form of business activities, which is part of the micro, small, and medium enterprises. Fast cash turnover is one of the main characteristics of this business. Therefore, the profit can be used to increase its business capital. As this kind of business is generally engaged in the real sector, the types of products and prices are competitive among them. Therefore, the company must plan its business processes from production to marketing. Consequently, an optimization strategy must be made. In order to increase profit, one of the possible strategies is by optimizing production processes through a linear programming method as suggested by [1], [2], [3], and [4]. These previous studies used the linear programming method to find the most feasible ways to increase profit, maximize revenue, minimize costs, as well as to optimize available resources and production process in the context of organizations in Indonesia. Other researchers from abroad such as [5], [6], [7], [8], [9], [10], and [11] have also used linear programming to leverage profit, minimize costs, evaluate employee performance, and minimize transportation costs at different activities of organization. Hence, based on the previous studies, linear programming method has been used globally and proven to be effective in identifying the most optimum strategies to improve various organizational activities, including production processes, while helping the organizations to increase profit.

This paper discusses how the optimization of the production process can help to increase the profits of a micro SME. This case study was conducted in "XL home industry" in Jakarta, 
which produces variety of women clothes, such as tanktop (or sleeveless shirt), short and long leggings. These three products are produced with the same machines and workers with different proportions. In addition, the products also use the same raw materials. Table 1 shows the monthly actual production level along with its monthly targets in year 2018.

Table 1. Monthly Actual Production Level and Targets of XL Home Industry (July to December 2018 , in dozen)

\begin{tabular}{lcccc}
\hline \multicolumn{1}{c}{ Month } & Tanktop & Short Legging & Long Legging & Total \\
& & & & \\
\hline December & 1400 & 214 & 37 & 1651 \\
November & 1462 & 50 & - & 1512 \\
October & 1360 & 315 & 79 & 1754 \\
September & 1169 & 124 & 32 & 1325 \\
August & 1407 & 127 & - & 1186 \\
July & 1094 & 88 & 200 & 3250 \\
\hline Monthly Target & 2700 & 350 & & \\
\hline
\end{tabular}

Table 1 shows that the most production is tanktop, while the least production is long leggings. As the long leggings are produced in small quantity, its contribution to the company's profit is the smallest. Besides, its monthly production target was not achieved. This remains an intriguing question, will the long leggings continue being produced?

Based on the background, the research problem is formulated; can the strategy optimize the profit be obtained by using a linear programming method through a sensitivity analysis? Can the linear programming increase production so that the targets are achieved effectively and efficiently?

\section{Literature Review}

Linear programming is one of the most common tools used in various fields to solve the optimization (maximization or minimization) problems [12], such as to optimize limited resources [13], utilization of resources [3], to maximize profits [7], and to minimize costs [14]. According to [6], the problem of linear programming can be stated as a linear objective function as follows:

$$
\mathrm{Z}=c_{1} x_{1}+c_{2} x_{2}+\ldots+c_{n} x_{n}
$$

With the following constraints:

$$
\begin{aligned}
& a_{11} x_{1}+a_{12} x_{2}+\ldots+a_{1 n} x_{n}(\leq,=, \geq) b_{1} \\
& a_{21} x_{1}+a_{22} x_{2}+\ldots+a_{2 n} x_{n}(\leq,=, \geq) b_{2} \\
& a_{m 1} x_{1}+a_{m 2} x_{2}+\ldots+a_{m n} x_{n}(\leq,=, \geq) b_{m}
\end{aligned}
$$

And

Where:

$$
x_{1}, x_{2}, \ldots, x_{n} \geq 0
$$

$\mathrm{m}$ = types of resource constraints or facilities available

$\mathrm{n}=$ types of activities that use available resources or facilities

$\mathrm{j}=$ number of each type of activities that uses the available resources or facilities

$x_{i}=$ decision of variable $\mathrm{i}$

$a_{i j}=$ Number of resources $\mathrm{i}$ needed to produce each activity unit of output $\mathrm{j}$ 


$$
\begin{aligned}
& \mathrm{Z}=\text { optimized value } \\
& c_{n}=\text { the contribution of each unit of activity output } \mathrm{n} \text { to the value of } \mathrm{Z}
\end{aligned}
$$

The linear programming can be done graphically with a simplex method [15][7]. Sensitivity analysis is post optimality analysis so that an optimum solution can be obtained [13]. This analysis is done by making changes to the objective function, constraints function, objective function coefficient, constraints function coefficient, number of available resource constraints, and the addition of new constraints and products.

\section{Research Methods}

This research was a quantitative method with a case study approach. Data was collected through an observation The data include production process and machines used, machine hours, the time needed to produce one unit of product, amount of raw materials required for each product, available raw materials, labor costs, and prices of raw materials. Based on the data, the objective and constraint equations were constructed. Subsequently, the data were analyzed by using POM software for Windows. Table 2 shows the calculation of profit for each decision variable.

Table 2. Calculation of profit per product

\begin{tabular}{lrcc}
\hline & Tanktop & Short legging & Long Legging \\
\hline Tc-per product & 109.926 .85 & 96735.71 & 162450 \\
Price & 130.000 & 125.000 & 190.000 \\
Profit & 20073.148 & 28264.29 & 27550 \\
\hline
\end{tabular}

Furthermore, the objective function equation can be formed as follows:

$$
z_{\max }=20.074 x_{1}+28.265 x_{2}+27.550
$$

The function of constraints depends on the availability of raw materials, labors and machines. To measure the time required for each production process, a stopwatch was used. The raw materials include spandex rayon, spandex balloons, and spandex polyester, whereas the machines are cutting machines, overlock machines, and over deck machines. The constraint function equations are as follows:

$$
\begin{aligned}
& \text { 1. } 1,6 x_{1}+1 x_{2}+1,6 x_{3} \leq 12.000 \\
& \text { 2. } 4 x_{1}+6 x_{2}+8,8 x_{3} \leq 48.000 \\
& \text { 3. } 5,4 x_{1}+5,2 x_{2}+8 x_{3} \leq 60.000 \\
& \text { 4. } 6 x_{1}+4 x_{2}+6 x_{3} \leq 48.000 \\
& \text { 5. } 11,5 x_{1} \leq 4.500 \\
& \text { 6. } 1 x_{2} \leq 350 \\
& \text { 7. } 2 x_{3} \leq 450
\end{aligned}
$$

\section{Result and Analysis}

By using the POM software for windows, the optimum solution was obtained. Tanktop, short leggings, and long leggings should be produced 3000 dozen, 350 dozen, and 225 dozen per month, respectively. With this composition, the company is expected to obtain a profit of Rp. 76.313.500,- 
Furthermore, sensitivity analysis with POM software for Windows provided an optimum solution, as presented in Table 3 .

Tabel 3. Summary of Sensitivity Analysis Results -1

\begin{tabular}{llllll}
\hline & $\begin{array}{l}\text { Dual } \\
\text { Value }\end{array}$ & Slack/Surplus & $\begin{array}{l}\text { Original } \\
\text { Val }\end{array}$ & $\begin{array}{l}\text { Lower } \\
\text { Bound }\end{array}$ & $\begin{array}{l}\text { Upper } \\
\text { Bound }\end{array}$ \\
\hline Cutting machine & 0 & 6490 & 12000 & 5510 & Infinity \\
Overlock machine & 0 & 31920 & 48000 & 16080 & Infinity \\
Overdeck machine & 0 & 40180 & 60000 & 19820 & Infinity \\
Labor & 0 & 27250 & 48000 & 20750 & Infinity \\
Spandex rayon & 13382.67 & 0 & 4500 & 0 & 10584.38 \\
Spandex balon & 28265 & 0 & 350 & 0 & 5670 \\
Spandex polyester & 13775 & 0 & 450 & 0 & 7704.55 \\
\hline
\end{tabular}

A large number of working hours of machines and labors are not used in the production (see Slack/surplus) because of the limited raw materials. However, $1 \mathrm{~kg}$ of raw materials would still increase the company's profit. Due to this condition, recalculation was done by changing the amount of available raw materials in constraints 5, 6 and 7 by using upper bound. The result shows that tanktop products should be produced 4,285.71 dozen, short leggings $5,142.86$ dozen, and long leggings are not produced. By this composition, the profit of Rp. 231.394.300 is expected. By using the upper bound of raw materials, machine and raw materials can be optimized, which therefore will increase the profit. Even though the machines in constraint 1 and 2 have been used up, raw materials are still remaining (see table 4). Therefore, optimization has not reached.

Table 4. Summary of Sensitivity Analysis Results-2

\begin{tabular}{llllll}
\hline & Dual Value & Slack/Surplus & Original Val & Lower Bound & $\begin{array}{l}\text { Upper } \\
\text { Bound }\end{array}$ \\
\hline Cutting machine & 1318.57 & 0 & 12000 & 11262 & 12480 \\
Overlock machine & 4491.07 & 0 & 48000 & 32484.98 & 49845 \\
Overdeck machine & 0 & 10114.29 & 60000 & 49885.71 & Infinity \\
Labor & 0 & 1714.29 & 48000 & 46285.71 & Infinity \\
Spandex rayon & 0 & 4155.81 & 10584.38 & 6428.57 & Infinity \\
Spandex balon & 0 & 527.14 & 5670 & 5142.86 & Infinity \\
Spandex polyester & 0 & 7704.55 & 7704.55 & 0 & Infinity \\
\hline
\end{tabular}

A simulation was repeated by changing the availability of raw materials in constraints 5,6 , and 7 with lower bound of the last calculation. The simulation yields the same optimal solution. The output shows that tanktop should be produced 4285.71 dozen, short leggings 5,142.86 dozen, and long leggings are not produced. With this composition, the expected value of the profit is Rp. 231.394.300.

Table 5. Summary of Sensitivity Analysis Results-3

\begin{tabular}{llllll}
\hline & $\begin{array}{l}\text { Dual } \\
\text { Value }\end{array}$ & Slack/Surplus & Original Val & Lower Bound & Upper Bound \\
\hline Cutting machine & 0 & 0 & 12000 & 12000 & Infinity \\
Overlock machine & 4710.83 & 0 & 48000 & 17142.85 & 48000.0 \\
Overdeck machine & 0 & 10114.29 & 60000 & 49885.71 & Infinity
\end{tabular}




\begin{tabular}{llllll} 
Labor & 0 & 1714.29 & 48000 & 46285.71 & Infinity \\
Spandex rayon & 820.44 & 0 & 6428.57 & 6428.57 & 6428.57 \\
Spandex balon & 0 & 0 & 5142.86 & 5142.86 & Infinity \\
Spandex polyester & 0 & 0 & 0 & 0 & Infinity \\
\hline
\end{tabular}

Different from the first simulation, there was no raw material leftover and the remaining time on the machine and labor working hours was not excessive. Of course, this is possible with the absence of defective raw materials. However, in practice, the raw materials should be exaggerated to cater to any unexpected conditions. Table 6 shows the percentage of profits against raw material costs before and after sensitivity analysis. The table shows that the percentage of profit after the sensitivity analysis is higher. As an implication, there should be sufficiently strict supervision in carrying out the production process. The increase in costs of $119.88 \%$ increases a profit of $37,5 \%$.

Table 6. Percentage of Profits against the Cost of Raw Materials Before and After Sensitivity Analysis

\begin{tabular}{ccc}
\hline \multicolumn{2}{c}{ Before sensitivity analysis } & After sensitivity analysis \\
\hline Raw Material Cost (Rp) & $315,750,000$ & $694,285,800$. \\
Profit (Rp) & $76,313,500$. & $231,394,300$. \\
Comparison Ratio & 0,24 & $0,33$. \\
\hline Profit/Total Raw Material cost & $24 \%$ & $33 \%$ \\
\hline
\end{tabular}

As an implication of this optimization, the production targets of tanktop and short legging should be increased as much as $58.73 \%$, and $1369.39 \%$, respectively (see Table 7). The increase in these targets implies that the company should expand its markets in order to stay profitable.

Table 7. Changes to targets

\begin{tabular}{lccc}
\hline & Tanktop & Short legging & Long legging \\
\hline Target & 2700 & 350 & 200 \\
Optimization Result & 4285.71 & 5142.86 & 0 \\
increment & 1585.71 & 4792.86 & \\
Percentage & 58.73 & 1369.39 & \\
\hline
\end{tabular}

\section{Conclusion}

Based on the discussion above, this study concludes the followings:

1. Sensitivity analysis was applied successfully to suggest the most optimum strategy to increase the profits of XL Home Industry.

2. The sensitivity analysis suggests increasing the production target of the tanktop and short legging products by $58.73 \%$ and $1369.39 \%$, respectively.

3. The analysis also found that an increase in costs of $119.88 \%$ contributes to the increase in profit of $37.5 \%$. 
4. By applying this optimization results, XL Home Industry can increase its profits from $24 \%$ to $33 \%$. Thus, the additional raw material costs give a significant increment of profit.

\section{References}

[1] M. Anis and S. Nandiroh, "Optimasi Perencanaan Produksi Dengan Metode Goal Programming," J. Ilm. Tek. Ind., vol. 5, no. 3, pp. 133-143, 2007.

[2] A. A. S. Desiana, S. Dewi, and K. Sari, "Analisis Sensitivitas dalam Optimalisasi Keuntungan Produksi Busana dengan Metode Simpleks,” vol. 4, no. 2, pp. 90-101, 2014.

[3] A. Supriyadi, Muslimat, R. Pratama, and G. Ramayanti, "Implementasi Linear Programming Untuk Memaksimalkan Keuntungan I mplementasi Linear Programming Untuk M emaksimalkan K euntungan," Semin. Nas. Ris. Terap. 2017 | SENASSET 2017, no. November, pp. 183-189, 2017.

[4] Trihudiyatmanto, “Analisis Aplikasi Linear Programming Untuk Mendapatkan Jumlah Produksi yang Optimal Dalam Memperoleh Keuntungan Maksimal,” 2019.

[5] I. A. Akpan, N. P.\& Iwok, "Application of Linear Programming for Optimal Use of Raw Materials in Bakery,” Int. J. Math. Stat. Invent., vol. 4, no. 8, pp. 51-57, 2016.

[6] I. . Fagoyinbo, I. S and Ajibode, "Application of Linear Programming Techniques in the Effective Use of Resources for Staff Training," J. Emerg. Trends Eng. Appl. Sci. 1(2), vol. 1, no. 2, pp. 127-132, 2010.

[7] K. M. Gupta, "Application of Linear Programming Techniques for Staff Training," vol. 3, no. 12, pp. 132-135, 2014.

[8] L. U. Uko, G. G. College, R. J. Lutz, G. G. College, J. A. Weisel, and G. G. College, "An Application of Linear Programming in Performance Evaluation," vol. 21, no. 1, pp. 1-7, 2017.

[9] Z. et al Haider, "Application of Linear Programming for Profit Maximization : A Case of Paints," Int. J. Manag. Sci. Bus. Res., no. 12, pp. 144-151, 2016.

[10] 3Akingbade .T.J. and 1Akinrefon .A.A Balogun .O.S. 2 Role .M.R., "Application Of Linear Programming In A Manufacturing Company In Feed Masters, Kulende, Kwara State.," no. May 2014, 2013.

[11] V. N. Maurya, R. B. Misra, P. K. Anderson, and K. K. Shukla, "Profit Optimization Using Linear Programming Model : A Case Study of Ethiopian Chemical Company," Am. J. Biol. Environ. Stat., vol. 1, no. 2, pp. 51-57, 2015.

[12] Puryani and A. Ristono, Penelitian Operasional, Pertama. Yogyakarta: Graha Ilmu, 2012.

[13] B. Heizer, J., \& Render, Operations Management, 7th editio. New Jersey: Pearson Education., 2014.

[14] H. Siringoringo, Seri Teknik Riset Operasional. Pemrograman Linear. Yogyakarta: Grha Ilmu, 2005.

[15] M. S. Lord, "Linear Programming \& Optimizing the Resources," Interdiscip. J. Contemp. Res. Bus., vol. Vol 4, No, pp. 701-705, 2013. 